\title{
Sensory evaluation of beef and buffalo extensively reared and its relationship to sociodemographic characteristics of consumers
}

\section{Avaliação sensorial de carne bovina e bubalina de animais criados a pasto e sua relação com as características sociodemográficas dos consumidores}

\author{
Maria Eugênia Andrighetto Canozzi ${ }^{1}$; Luiza Ávila Sphor ${ }^{1}$; \\ Concepta Margaret McManus Pimentel2; Júlio Otávio Jardim Barcellos ${ }^{3}$; \\ César Henrique Espirito Candal Poli ${ }^{3}$; Guiomar Pedro Bergmann ${ }^{4}$; Liris Kindlein ${ }^{4 *}$
}

\begin{abstract}
Sensory characteristics of meat from different animal types, including cattle (Angus and Brangus) and buffalo raised at pasture, and information on socio-demographic determinants of consumer preference were evaluated. Samples of roasted rib eye were cut and served in a disordered and monadic manner to 188 untrained tasters. A nine-point hedonic scale was used to assess odor, color, tenderness, succulence and overall appearance. Analysis of variance was carried out using the GLM procedure of $\mathrm{SAS} \otimes$, considering animal type and socio-demographic characteristics as fixed effects and using the LSMEANS procedure for multiple mean comparisons. Differences $(\mathrm{P}<0.001)$ between animal types were observed only for tenderness, with Brangus (7.02) and buffalo (6.82) meat being superior to Angus (6.25). Regardless of meat origin, age, income, smoking and place of purchase affected the perceived attributes $(\mathrm{P}<0.05)$. People aged over 50 years gave higher mean scores for odor and color $(\mathrm{P}<0.05)$, indicative of greater satisfaction and less demanding tastes when compared to other age categories. Despite the variability in the intrinsic characteristics, differentiation of meat by the consumer is not easy to determine, with little impact of sociodemographic characteristics on organoleptic perception. Meat from Brangus cattle and buffaloes raised at pasture was considered tenderer than that from Angus cattle raised under the same conditions by an untrained taste panel compared with.
\end{abstract}

Key words: Beef. Palatability. Quality. Sensorial panel.

\section{Resumo}

Avaliaram-se as características sensoriais da carne de diferentes espécies (bovina e bubalina) e raças (Angus e Brangus) criadas a pasto (campo nativo), além dos determinantes sociodemográficos de preferência dos consumidores, através de painel sensorial. Amostras de Longíssimus dorsi foram assadas, cortadas e servidas de forma desordenada e monádica a 188 painelistas não-treinados sediados

\footnotetext{
${ }^{1}$ Discentes do Programa de Pós-Graduação em Zootecnia, Universidade Federal do Rio Grande do Sul, UFRGS, Porto Alegre, RS, Brasil. E-mail: mecanozzi@yahoo.com.br; 1sphor@homail.com

${ }^{2}$ Prof $^{\mathrm{a}}$, Dr ${ }^{\mathrm{a}}$, Faculdade de Agronomia e Medicina Veterinária, FAV, Universidade de Brasília, UnB, Brasília, DF, Brasil. E-mail: concepta@unb.br

${ }^{3}$ Profs., Drs., Dept ${ }^{\circ}$ de Zootecnia, Universidade Federal do Rio Grande do Sul, UFRGS, Porto Alegre, RS, Brasil. E-mail: julio. barcellos@ufrgs,br; cesar.poli@ufrgs.br

${ }^{4}$ Profs., Drs., Faculdade de Medicina Veterinária, Universidade Federal do Rio Grande do Sul, UFRGS, Porto Alegre, RS, Brasil. E-mail: guiomar.bergmann@ufrgs.br; liris.kindlein@ufrgs.br

* Author for correspondence
} 
no Estado do Rio Grande do Sul, Brasil. Foi utilizada uma escala hedônica de nove pontos para avaliar os atributos odor, cor, maciez, suculência e aparência global. Através do procedimento GLM - SAS ${ }^{\circledR}$ realizou-se a análise de variância, considerando as características sensoriais e sociodemográficas como fatores fixos. Quando o fator apresentou efeito significativo $(\mathrm{P}<0,05)$, foi utilizado LSMEANS para comparação entre as médias. Foi encontrada diferença $(\mathrm{P}<0,001)$ somente para o atributo maciez, com as carnes de bovinos da raça Brangus e de bubalinos apresentando maior grau, com 7,02 e 6,82, respectivamente, quando comparados com a de bovinos da raça Angus $(6,25)$. Independente da origem da carne, a idade, a renda, o hábito de fumar e o local de compra dos consumidores foram determinantes para parte dos atributos avaliados $(\mathrm{P}<0,05)$. Pessoas com idade superior a 50 anos conferiram escores médios superiores (5,86 e 7,36 para odor e cor, respectivamente; $\mathrm{P}<0,05)$, indicativo de maior grau de satisfação e menor exigência, quando comparados às outras categorias de idade. Apesar da variabilidade nas características intrínsecas, a diferenciação da carne pelo consumidor é abstrusa, havendo pequeno impacto dos aspectos sociodemográficos nos atributos sensoriais. As carnes de bovinos Brangus e de bubalinos criados extensivamente apresentaram maior maciez que a de bovinos Angus criados no mesmo sistema.

Palavras-chave: Carne. Suculência. Qualidade. Painel sensorial.

\section{Introduction}

Providing a healthy, safe, nutritional and high quality product will guarantee the continued consumption of meat (WARNER et al., 2010). However, as this quality is guided by consumer expectations and perceptions (ISSANCHOU, 1996), product acceptance depends on sensory attributes, nutritional, cultural and convenience aspects as well as those that impact their health (MONSÓN et al., 2005).

Consumer preferences are constantly subject to change (ISSANCHOU, 1996; KILLINGER et al., 2004) and the offer of homogeneous meat products is limited, due to the variability of production, technological and intrinsic factors (RAES et al., 2003). In the case of intrinsic characteristics, sensory attributes stand out in building consumer opinion and acceptability (KRYSTALLIS; ARVANITOYANNIS, 2006). Furthermore, the influence of breed and species-related factors, responsible for the composition and appearance of the product, are contentious (OLIVER et al., 2006), as is the type of breeding and nutrition system that provide meat with distinct characteristics. According to Menezes et al. (2010), evaluating the meat of young Devon steers finished in different feeding systems shows that the meat obtained from temperate pasture systems is darker and lower tenderness compared to that obtained from animals finished in feedlot or in on tropical pasture, which produce more tender, though less palatable.

For many years, the importance of social and demographic criteria among individuals and groups, with regards to sensory factors, was largely neglected (ISSANCHOU, 1996). However, as from the 1990s, populational characteristics, such as income, age and nationality, were measured for the first time and considered determinants in the sensory perception of meat (HUFFMAN et al., 1996; KILLINGER et al., 2004; OLIVER et al., 2006; HWANG et al., 2008).

With this in mind, the sensory characteristics of meat from different species - bovine and buffalo and breeds - Angus and Brangus - raised at pasture was evaluated, along with sociodemographic determinants of consumer preference in State of Rio Grande do Sul, Brazil, through a sensorial panel.

\section{Materials and Methods}

All procedures described in this paper where previously submitted to the Research Ethics Committee of the Federal University of Rio Grande do Sul (CEP/UFRGS) and accepted according to 
Protocol $\mathrm{n}^{\circ}$ 17932/11. Additionally, participants signed a term of Free and Informed Consent and, before answering the questionnaire, they were informed of the nature of and procedures involved in the study, which complies with the regulation for research with humans (CNS, 196/1996).

The meat samples were donated by breeder associations for each breed and originated from animals raised in a pasture-feeding system in the Pampa region of Rio Grande do Sul, on pasture characterized as grassy-woody savanna (native grassland).

Samples were cut into $2.5 \mathrm{~cm}$ steaks from the ribeye (Longissimus dorsi) area of the left hind quarters of Angus and Brangus cattle and buffalo, taken from between the $12^{\text {th }}$ and $13^{\text {th }}$ rib and used for sensorial analysis. Cuts were seasoned with sodium chloride at $1 \%$ so as not to influence consumer palatability, at room temperature (approximately $23^{\circ} \mathrm{C}$ ), for an hour. Later, they were roasted in a preheated oven at $170^{\circ} \mathrm{C}$ until temperature reached $72^{\circ} \mathrm{C}$ in the geometric center, controlled by thermocouple probe, in accordance with recommendations from the American Meat Society Association (AMSA, 1978). Lastly, they were cut into standard sizes (2 $\mathrm{cm}^{3}$ cubes), wrapped in aluminum foil and placed in closed beakers in a bain-marie at $60^{\circ} \mathrm{C}$ to conduct the sensorial analysis.

The study was held at the UFRGS booth during the International Animal and Agricultural Machinery, Implements and Products Expo (EXPOINTER), in the municipality of Esteio, in Rio Grande do Sul, Brazil, in 2012. Criteria for taking part in the research meant that tasters had to be Brazilian, residents of the State, aged over 18 and potential or habitual consumers of beef (consumption greater than twice a week).

Initially, 188 panelists were instructed to answer a pre-drafted questionnaire on sociodemographic characteristics (gender, age, smoker/non-smoker, monthly income, regularity of beef consumption, place of purchase and the manner of presentation). The analysis of sensory characteristics was conducted by untrained tasters, in an individual booth under controlled temperature and lighting conditions. According to Hwang et al. (2008), the advantage of conducting research with untrained people is that they offer a more accurate reflection of society's preferences.

The samples were served in a monadic and disordered manner, in coded plastic containers with three digit references of the respective treatments (meat from different species/breed). They were accompanied by a list of descriptive terms, a saltine cracker to remove residual flavor, in addition to water at room temperature to cleanse the palate.

Assessed attributes included: color, flavor (sensation of taste and odor released by the sample while chewing), tenderness (perception of force necessary to slice the sample by biting at the height of the molars), succulence and overall appearance (the sum of all the sensory perceptions expressing the opinion of the judges regarding the quality of the product). As such, an unstructured nine-point hedonic scale was used: 1 - dislike extremely, 2 dislike very much, 3 - dislike moderately, 4 - dislike slightly, 5 - neither like nor dislike, 6 - like slightly, 7 - like moderately, 8 - like very much, 9 - like extremely, according to the methodology described by Moraes (1993).

The statistical analysis of data collected was conducted using SAS $^{\circledR}$ v. 9.3 (Statistical Analysis System, Cary, North Carolina). Analysis of variance was conducted using the GLM procedure, considering sociodemographic and sensory characteristics as fixed effects. When the factor presents a significant effect $(\mathrm{P}<0.05)$, the LSMEANS (Least Squared Means) was used to compare the means. The Spearman correlation (PROC CORR) was used to assess the association among the five studied sensory attributes, considering a significance level of $\mathrm{P}<0.0001$. 


\section{Results}

The 188 interviewees were aged between 18 and 77 years $(52.94 \%$ men and $47.06 \%$ women). Of all those interviewed, a minority $(12.57 \%)$ were smokers. Regarding salary level, half of the sample had monthly earnings greater than six minimum wages $(49.72 \%)$ and a minority $(15.82 \%)$ earned two minimum wages. Approximately half of those interviewed (58.06\%) consumed meat more than four times a week, while $2.15 \%$ only ate meat at weekends. Regarding place of purchase, product acquisition was mainly from supermarkets and butcheries $(82 \%)$ and the majority ( $83.98 \%)$ stated they buy chilled meats (Table 1).

Table 1. Sociodemographic characteristics of beef consumers in Rio Grande do Sul.

\begin{tabular}{|c|c|c|c|}
\hline Characteristics & Categories & $\mathbf{n}$ & $\%$ \\
\hline \multirow[t]{2}{*}{ Gender } & Male & 99 & 52.94 \\
\hline & Female & 88 & 47.06 \\
\hline \multirow[t]{3}{*}{ Age } & $18-35$ & 98 & 56.65 \\
\hline & $36-49$ & 44 & 25.43 \\
\hline & $\geq 50$ & 31 & 17.92 \\
\hline \multirow[t]{2}{*}{ Smoker } & Yes & 22 & 12.57 \\
\hline & No & 153 & 87.43 \\
\hline \multirow[t]{3}{*}{ Income ${ }^{*}$} & 2 m.w. & 28 & 15.82 \\
\hline & 3-6 m.w. & 61 & 34.46 \\
\hline & $>6$ m.w. & 88 & 49.72 \\
\hline \multirow[t]{4}{*}{ Consumption regularity } & Weekend & 4 & 2.15 \\
\hline & $1-2$ & 15 & 8.06 \\
\hline & $3-4$ & 59 & 31.72 \\
\hline & $>4$ & 108 & 58.06 \\
\hline \multirow[t]{4}{*}{ Place of purchase } & Butchery & 64 & 34.22 \\
\hline & Supermarket & 90 & 48.13 \\
\hline & Butcher and supermarket & 5 & 2.67 \\
\hline & Other & 28 & 14.97 \\
\hline \multirow[t]{4}{*}{ Form of presentation } & Chilled & 152 & 83.98 \\
\hline & Frozen & 24 & 13.26 \\
\hline & Pre-cooked & 1 & 0.55 \\
\hline & Chilled and frozen & 4 & 2.21 \\
\hline
\end{tabular}

*Based on Brazilian minimum wage (m.w.) in 2010 (BRL 510.00).

For consumer acceptability, based on meat cattle and buffalo presented a superior grade, at 7.02 sensory characteristics, differences $(\mathrm{P}<0.001)$ were and 6.82, respectively, when compared with Angus only observed for tenderness: meat from Brangus cattle (6.25) (Table 2). 
Table 2. Average values of scores for sensory attributes for the evaluated meats.

\begin{tabular}{lccccc}
\hline Sample & Odor & Color & Tenderness & Succulence & Overall appearance \\
\hline Angus & 5.53 & 6.96 & $6.25^{\mathrm{b}}$ & 5.60 & 6.61 \\
Brangus & 5.53 & 6.92 & $7.02^{\mathrm{a}}$ & 6.02 & 6.54 \\
Bubalus (Buffalo) & 5.56 & 6.68 & $6.82^{\mathrm{a}}$ & 5.72 & 6.36 \\
Pr $>$ F & 0.98 & 0.35 & 0.0008 & 0.23 & 0.50 \\
\hline
\end{tabular}

Based on the unstructured 9-point Hedonic scale: 1 - dislike extremely. 2 - dislike very much. 3 - dislike moderately. 4 - dislike slightly. 5 - neither like nor dislike. 6 - like slightly. 7 - like moderately. 8 - like very much. 9 - like extremely. Averages in the same column followed by a different letter differ statistically $(\mathrm{P}<0.05)$ through Tukey's test.

Positive and significant correlations $(\mathrm{P}<0.0001)$ were found between all sensory variables. For the overall appearance a higher correlation (0.79) was noted, while general appearance and tenderness showed a lower value (0.56) (Table 3).

Table 3. Correlations between sensory attributes of meat regardless of the assessed species/breed.

\begin{tabular}{lccccc}
\hline & Odor & Color & Tenderness & Succulence & Overall appearance \\
\hline Odor & - & $0.43^{*}$ & $0.26^{*}$ & $0.39^{*}$ & $0.41^{*}$ \\
Color & $0.43^{*}$ & - & $0.27^{*}$ & $0.38^{*}$ & $0.79^{*}$ \\
Tenderness & $0.26^{*}$ & $0.27^{*}$ & - & $0.56^{*}$ & $0.34^{*}$ \\
Succulence & $0.39^{*}$ & $0.38^{*}$ & $0.56^{*}$ & - & $0.44^{*}$ \\
General appearance & $0.41^{*}$ & $0.79^{*}$ & $0.56^{*}$ & $0.44^{*}$ & - \\
\hline
\end{tabular}

Level of significance used in the correlation analyses $* \mathrm{P}<0.0001$.

For social and demographic analysis, regardless of the sample, there was a noted lack of any significant effect for gender, regularity of consumption and form of presentation of the acquired product in relation to sensory attributes. However, the age of the tasters had an influence on meat odor and color. People aged over 50 years gave higher mean scores for these attributes (5.86 and 7.36, respectively; $\mathrm{P}<0.05$ ) when compared to other age brackets. Smoking habits influenced meat odor and tenderness characteristics, with nonsmokers presenting higher mean scores compared to smokers $(\mathrm{P}<0.05)$. Income was a determinant factor for four of the five attributes assessed: odor, color, tenderness and succulence. People with low incomes (two minimum wages) gave the highest scores for all attributes, with an increase in income leading to scores that tended to decrease on average. Lastly, the place of purchase was a determinant in the perception of the meat color: consumers that acquired meat in supermarkets conferred higher scores (like moderately) in comparison to those who purchased in butcheries, supermarkets and others (like slightly), differing statistically $(\mathrm{P}<0.05)$ from those who purchase at "other places" (Table 4).

\section{Discussion}

\section{Consumer profile}

In recent years, major changes have affected the offer of and demand for food, with meals now less representative in total family spending, mainly due to an increase in income (TAMBURO; 
GIL ROIG, 2003). Furthermore, according to Schlindwein and Kassouf (2006), no individual characteristic affects the possibility of purchasing more than financial availability. Innumerous surveys with consumers show that, regardless of the level of development of the country, interviewees with an elevated income tend to present higher spending on food products. In Rio Grande do Sul State, Brazil, Abicht (2009) found that $50.4 \%$ of meat consumers interviewed had a monthly income higher than BRL 4,001.00, while in Greece, approximately half of the sample earned between 734 and 1,320€ (KRYSTALLIS; ARVANITOYANNIS, 2006). Both corroborate with the results of this research, with $49.72 \%$ of potential or habitual beef consumers earning a monthly income greater than BRL 3,060.00.
Regularity of beef consumption is variable among countries and regions. In Spain, the majority of consumers $(53.5 \%)$, as with the results of this study $(58.06 \%)$, consumed meat more than four times a week (MONSÓN et al., 2005). In Athens (Greece), consumption is between once and twice a week (KRYSTALLIS; ARVANITOYANNIS, 2006), and in Chile consumption is three times a week (SCHNETTLER et al., 2008). There is an evident difference among regions in Brazil, a consequence of cultural habits, market availability and family income. For example, in Rio Grande do Sul State, in 2008, meat was consumed daily by $45.1 \%$ of interviewees and three times a week by $37.2 \%$ (ABICHT, 2009), while in Unai (Minas Gerais), $80 \%$ of consumers ate meat two to four times/week (COSTA; BRISOLA, 2005).

Table 4. Sensory analysis in accord with the social and demographic profile regardless of the assessed breed/species.

\begin{tabular}{|c|c|c|c|c|c|}
\hline $\begin{array}{l}\text { Sociodemographic } \\
\text { Characteristics }\end{array}$ & Odor & Color & Tenderness & Succulence & $\begin{array}{c}\text { Continue } \\
\text { Overall } \\
\text { appearance }\end{array}$ \\
\hline \multicolumn{6}{|l|}{ Gender } \\
\hline Male & 5.57 & 6.97 & 6.84 & 5.72 & 6.58 \\
\hline Female & 5.51 & 6.73 & 6.55 & 5.84 & 6.42 \\
\hline $\operatorname{Pr}>\mathrm{F}$ & 0.69 & 0.18 & 0.11 & 0.59 & 0.39 \\
\hline \multicolumn{6}{|l|}{ Age } \\
\hline $18-35$ & $5.24^{\mathrm{b}}$ & $6.63^{\mathrm{b}}$ & 6.48 & 5.58 & 6.24 \\
\hline $36-49$ & $5.52^{\mathrm{ab}}$ & $6.55^{\mathrm{b}}$ & 6.79 & 5.77 & 6.46 \\
\hline$\geq 50$ & $5.86^{\mathrm{a}}$ & $7.36^{\mathrm{a}}$ & 6.82 & 6.00 & 6.81 \\
\hline $\operatorname{Pr}>F$ & 0.02 & 0.009 & 0.27 & 0.43 & 0.11 \\
\hline \multicolumn{6}{|l|}{ Smoker } \\
\hline $\mathrm{Y}$ & $5.32^{\mathrm{a}}$ & 6.94 & $6.38^{\mathrm{a}}$ & 5.51 & 6.44 \\
\hline $\mathrm{N}$ & $5.77^{\mathrm{b}}$ & 6.76 & $7.01^{\mathrm{b}}$ & 6.06 & 6.57 \\
\hline $\operatorname{Pr}>F$ & 0.04 & 0.46 & 0.01 & 0.07 & 0.62 \\
\hline \multicolumn{6}{|l|}{ Income $^{*}$} \\
\hline 2 m.w. & $5.99^{\mathrm{a}}$ & $7.22^{\mathrm{a}}$ & $7.15^{\mathrm{a}}$ & $6.34^{\mathrm{a}}$ & 6.72 \\
\hline 3-6 m.w. & $5.15^{\mathrm{b}}$ & $6.83^{\mathrm{ab}}$ & $6.56^{\mathrm{ab}}$ & $5.45^{\mathrm{b}}$ & 6.58 \\
\hline$>6$ m.w. & $5.48^{\mathrm{ab}}$ & $6.50^{\mathrm{b}}$ & $6.37^{\mathrm{b}}$ & $5.55^{\mathrm{ab}}$ & 6.22 \\
\hline $\operatorname{Pr}>F$ & 0.004 & 0.03 & 0.02 & 0.03 & 0.12 \\
\hline \multicolumn{6}{|c|}{ Consumption Regularity } \\
\hline Weekend & 4.78 & 6.73 & 6.91 & 4.48 & 5.88 \\
\hline $1-2$ & 5.44 & 6.86 & 6.31 & 6.09 & 6.77 \\
\hline $3-4$ & 5.93 & 6.98 & 6.72 & 6.21 & 6.67 \\
\hline
\end{tabular}




\begin{tabular}{|c|c|c|c|c|c|}
\hline & & & & & Continuation \\
\hline$>4$ & 6.01 & 6.83 & 6.85 & 6.35 & 6.69 \\
\hline $\operatorname{Pr}>\mathrm{F}$ & 0.11 & 0.88 & 0.43 & 0.26 & 0.77 \\
\hline \multicolumn{6}{|l|}{ Place of purchase } \\
\hline Butcher & 5.75 & $6.76^{\mathrm{ab}}$ & 6.74 & 6.05 & 6.47 \\
\hline Supermarket & 5.77 & $7.29^{\mathrm{a}}$ & 6.74 & 6.25 & 6.78 \\
\hline Butcher and supermarket & 5.41 & $6.90^{\mathrm{ab}}$ & 6.60 & 5.24 & 6.63 \\
\hline Other & 5.25 & $6.46^{\mathrm{b}}$ & 6.71 & 5.59 & 6.13 \\
\hline $\operatorname{Pr}>\mathrm{F}$ & 0.23 & 0.03 & 0.99 & 0.18 & 0.24 \\
\hline \multicolumn{6}{|l|}{ Form of presentation } \\
\hline Chilled & 5.90 & 6.33 & 7.28 & 5.74 & 6.12 \\
\hline Frozen & 5.61 & 6.36 & 7.02 & 6.31 & 5.83 \\
\hline Pre-cooked & 5.10 & 7.99 & 5.62 & 5.78 & 7.79 \\
\hline Chilled or frozen & 5.56 & 6.72 & 6.87 & 5.29 & 6.27 \\
\hline $\operatorname{Pr}>\mathrm{F}$ & 0.54 & 0.42 & 0.35 & 0.38 & 0.32 \\
\hline
\end{tabular}

*Based on Brazilian minimum wage (m.w.) in 2010 (BRL 510.00).

Based on the unstructured 9-point Hedonic scale: 1 - dislike extremely. 2 - dislike very much. 3 - dislike moderately. 4 - dislike slightly. 5 - neither like nor dislike. 6 - like slightly. 7 - like moderately. 8 - like very much. 9 - like extremely. Averages in the same column followed by a different letter differ statistically $(\mathrm{P}<0.05)$ through Tukey's test.

Preference for place of purchase found in this study is in accordance with that stated by Abicht (2009), who identified that $71.3 \%$ of interviewees preferred to acquire meat at supermarkets or markets and only $16.1 \%$ at butcheries. However, for families from the city of Athens (Greece), the most usual channel was the local butcher (45.5 to $55.6 \%$ ) (KRYSTALLIS; ARVANITOYANNIS, 2006). According to Costa and Brisola (2005), the quality of the product (color, flavor, odor, tenderness and succulence), good service and close relationships with the local butcher, among other factors, are determinants in the choice of place for purchasing beef.

The manner of beef presentation was the only purchase determinant in the survey conducted with North American consumers (BOLES; SWAN, 2002). According to these authors, the preference for chilled meat is because this presents higher succulence, flavor intensity and general acceptability, when compared to frozen products. This may also justify the preference of $83.98 \%$ of consumers from Rio Grande do Sul interviewed in this study, who acquired the product under this form of conservation.

\section{Acceptability score}

Despite buffalo meat presenting whiter fat and a more granular texture than beef (OLIVEIRA, 2005) coupled with reports of problems associated to palatability in Bos Indicus animals (CROUSE et al., 1989), the only attribute found to be different among species/breed was tenderness, with Brangus beef and buffalo rated superior according to Vilarinho et al. (2011) when carrying out a sensory analysis comparison between beef and buffalo. Research by Rodrigues and Andrade (2004) on the intrinsic characteristics of Nelore beef and buffalo meat showed less shear force and, as such, greater tenderness for buffalo meat, while sensory differences - flavor, aroma, tenderness, texture, succulence, color of the fat and meat and overall appearance - where not perceived by consumers (OHLY, 1997).

However, studies evaluating the beef from British breed and those crossbred with zebu showed that, with an increase in the level of crossbreeding, there was a trend in the increase of shear force and toughness, with a decrease in succulence and marbling (CROUSE et al., 1989; SCHERBECK et al., 1995; HIGHFILL et al., 2012). Boles and 
Swan (2002) found that, despite cattle of British origin being more succulent and tender, not as dry and presenting greater acceptability than Brahman animals, these variations did not impact the willingness to buy among North American consumers. These differences, resulting from breed and/or species, could be do a reflection of the quantity, solubility and space organization of collagen, fatness and calpain and calpastatin activity (MONSÓN et al., 2005), coupled with the amount and ease of fragmentation of connective tissue (CROUSE et al., 1989).

According to Huffman et al. (1996), consumer satisfaction with beef is largely due to tenderness (51\% of the responders), followed by flavor $(29 \%)$ and succulence (10\%). However, when the tenderness is acceptable, flavor determines satisfaction (RODAS-GONZÁLEZ et al., 2009). In addition to these attributes is the color, visible fat and freshness of meat at the time of purchase, while flavor and tenderness become more relevant than succulence only at consumption (BELLO ACEBRÓN; CALVO DOPICO, 2000).

As such, the importance of such research, which gauges the influence of species and breed on sensory characteristics, becomes evident. Crouse et al. (1989) identified similarities in sensory attributes for succulence and flavor intensity when comparing purebred taurine cattle to crossbred zebu cattle. Raes et al. (2003), on the other hand, found high average means for flavor intensity in beef from Irish and Argentine breeds when compared to those of Belgian or French origin (Double Muscled Belgian Blue and Limousin), possibly due from fat oxidation, as well as branched and aromatic aldehydes, resulting from proteolysis and amino acid degradation, and low scores for tenderness in Belgian beef, due to a higher collagen index. When comparing Spanish cattle breeds, Campo et al. (1999) did not find differences for succulence, although tenderness and odor presented differences with the sensory panel. The effects of European breeds was studied by Gregory et al.
(1994), who identified higher magnitudes in scores for tenderness among breeds than for succulence and flavor attributes. Results contrary to this study were found by Crouse et al. (1989) and Scherbeck et al. (1995), showing that as the percentage of Bos indicus increase led to a decrease in succulence.

According to Thompson (2002), and in line with the findings of this study, tenderness, succulence, flavor and acceptability are possibly correlated. There was evident variability in values: Australian consumers found greater correlation between tenderness and general acceptability (THOMPSON, 2002); Venezuelans, for flavor and general acceptability (RODAS-GONZÁLES et al., 2009); and consumers from Rio Grande do Sul, for color and overall appearance ( 0.79 in this study). As color is a reflection of the amount and chemical state of its main pigment, myoglobin, there is discrimination against darker meats (RODRIGUES; ANDRADE, 2004), which may form a basis for this result. Furthermore, nationality may influence correlation, as values for tenderness and general acceptability for beef was 0.81 for Germans and 0.79 for the Spanish and British (OLIVER et al., 2006), while the closest value to this study $(0.34)$ was that found by RodasGonzáles et al. (2009) among Venezuelans (0.44).

Many studies showed an association between marbling and sensory characteristics, such as tenderness, palatability, flavor and succulence (GREGORY et al., 1994; JEREMIAH, 1996; WARNER et al., 2010). Results similar to those from this study were obtained by Monsón et al. (2005), in which the correlation between general acceptability and tenderness was 0.52 (vs. 0.56); however authors found that the flavor attribute contributed most to consumer satisfaction $(\mathrm{r}=0.78)$, approximately double the correlation between overall appearance and succulence $(r=0.44)$ from this study.

\section{Social and demographic effects on sensory scores}

An analysis of sociodemographic aspects and sensory attributes is relevant due to the change in 
focus by the meat industry: in the past, it was steered through traditional production practices and, now, by consumers. As such, mapping preferences is fundamental and allows inter-individual differences to be revealed, as there is regular variation in sensory characteristics (ISSANCHOU, 1996).

In accordance with the findings here, a study conducted with Korean and Australian consumers showed little significance for sensory scores and sociodemographic profiles of the sample consumers (HWANG et al., 2008). Krystallis and Arvanitoyannis (2006) showed that age is the leading factor that differentiates consumer attitude in relation to meat, with younger people placing higher importance on intrinsic characteristics. The effect of age interfered in the evaluation of tenderness, succulence, general acceptability and flavor for barbecued meat for Australian consumers, while for Koreans age only influenced flavor (HWANG et al., 2008). In addition, succulence, flavor and palatability received higher scores with an increase in age when the meat was consumed at home, there being no trend when consumed at a restaurant (HUFFMAN et al., 1996). These findings were similar to those found in this study, though for other sensory attributes (odor and color).

Literary data shows that income did not influence assessment for tenderness, succulence, flavor and general acceptability and was independent of meat preparation type - barbecued or grilled and consumer nationality - Korean or Australian (HWANG et al., 2008). According to Huffman et al. (1996), income influenced tenderness, succulence, flavor and palatability only when the meat was consumed within the home, there being no difference for consumption at restaurants. According to these authors, high income earners have higher expectations and are more critical of characteristics and product quality attributes, as such there is no decrease in the mean scores for tenderness, succulence, flavor and general palatability. These results are in accordance with those reported in this study, which also showed this relationship between odor and color with mean values of 6.50 and 6.37 , respectively, by panelists with an income greater than six minimum wages.

Preference for meat is chiefly based on a perceptible criterion after purchasing (flavor), which can be assessed prior to purchase in accordance with visual characteristics (color, natural structure, fat content) (KRYSTALLIS; ARVANITOYANNIS, 2006), thus determining the quality of the product and consumer loyalty. In this study, color of the meat was noted as being related to the place of purchase, there being greater preference for and a custom of acquiring from supermarkets, despite a butcher shop being a space for greater exchange of information.

\section{Conclusions}

For consumers from Rio Grande do Sul State, Brazil, meat from Brangus cattle and buffalo presented a higher tenderness than from Angus cattle. Furthermore, regardless of origin, social and demographic effects had little impact on sensory scores, only age and income were fundamental factors in perceiving of odor, color, tenderness and succulence.

\section{Acknowledgments}

CAPES for funding and the Brazilian Angus Association - ABA, Brazilian Brangus Association and the Brazilian Buffalo Breeders Association $\mathrm{ABCB}$ for donating samples.

\section{References}

ABICHT, A. M. Percepções dos consumidores locais sobre a carne bovina certificada e rastreada. 2009. Dissertação (Mestrado em Agronegócios) - Centro de Estudos e Pesquisas em Agronegócio - Universidade Federal do Rio Grande do Sul, Porto Alegre.

AMERICAN MEAT SCIENCE ASSOCIATION AMSA. Guidelines for cookery and sensory evaluation of meat. Chicago: AMSA, 1978. 33 p. 
BELLO ACEBRÓN, L.; CALVO DOPICO, D. The importance of intrinsic and extrinsic cues to expected and experienced quality: an empirical application for beef. Food Quality and Preference, Oxford, v. 14, n. 11, p. 229-238, 2000.

BOLES, J. A.; SWAN, J. E. Processing and sensory characteristics of cooked roast beef: effect of breed, age, gender and storage condition. Meat Science, Oxford, v. 62, n. 4, p. 419-417, 2002.

CAMPO, M. M.; SAÑUDO, C.; PANEA, B.; ALBERTI, P.; SANTOLARIA, P. Breed type and ageing time effects on sensory characteristics of beef strip loin steaks. Meat Science, Oxford, v. 51, n. 4, p. 383-390, 1999.

COSTA, N. G.; BRISOLA, M. V. Comportamento dos agentes no processo de compra de carne bovina em açougues da cidade de Unaí/MG: uma análise a luz da economia dos custos de transação. In: CONGRESSO DA SOCIEDADE BRASILEIRA DE ECONOMIA E SOCIOLOGIA RURAL, 43., 2005, Ribeirão Preto. Anais... Ribeirão Preto: SOBER, 2005. CD-ROM.

CROUSE, J. D.; CUNDIFF, L. V.; KOCH, R. M.; KOOHMARAIE, M.; SEIDEMAN, S. C. Comparisons of Bos Indicus and Bos Taurus inheritance for carcass beef characteristics and meat palatability. Journal of Animal Science, Champaign, v. 67, n. 10, p. 2661-2668, 1989.

GREGORY, K. E.; CUNDIFF, L. V.; KOCH, R. M.; DIKEMAN, M. E.; KOOHMARAIE, M. Breed effects, retained heterosis, and estimates of genetic and phenotypic parameters for carcass and meat traits of beef cattle. Journal of Animal Science, Champaign, v. 72, n. 5, p. 1174-1183, 1994.

HIGHFILL, C. M.; ESQUIVEL-FONT, O.; DIKEMAN, M. E.; KROPF, D. H. Tenderness profiles of ten muscles from F1 Bos indicus X Bos taurus and Bos taurus cattle cooked as steaks and roast. Meat Science, Oxford, v. 90, n. 4, p. 881-886, 2012.

HUFFMAN, K. L.; MILLER, M. F.; HOOVER, L. C.; WU, C. K.; BRITTIN, H. C.; RAMSEY, C. B. Effect of beef tenderness on consumer satisfaction with steaks consumed in the home and restaurant. Journal of Animal Science, Champaign, v. 74, n. 1, p. 91-97, 1996.

HWANG, I. H.; POLKINGHORNE, R.; LEE, J. M.; THOMPSON, M. Demographic and design effects on beef sensory scores given by Korean and Australian consumers. Australian Journal of Experimental Agriculture, Clayton South VIC, v. 48, n. 11, p. 13871395, 2008.
ISSANCHOU, S. Consumer expectations and perceptions of meat and meat product quality. Meat Science, Oxford, v. 43, n. 1, p. S5-S19, 1996.

JEREMIAH, L. E. The influence of subcutaneous fat thickness and marbling on beef. Food Research International, Amsterdam, v. 29, n. 5-6, p. 513-520, 1996.

KILLINGER, K. M.; CALKINS, C. R.; UMBERGER, W. J.; FEUZ, D. M.; ESKRIDGE, K. M. Consumer visual preference and value for beef steaks differing in marbling level and color. Journal of Animal Science, Champaign, v. 82, n. 1, p. 3288-3293, 2004.

KRYSTALLIS, A.; ARVANITOYANNIS, I. S. Investigating the concept of meat quality from the consumers' perspective: the case of Greece. Meat Science, Oxford, v. 72, n. 1, p. 164-176, 2006.

MENEZES, L. F. G.; RESTLE, J.; BRONDANI, I. L.; SILVEIRA, M. F.; FREITAS, L. S.; PIZZUTI, L. Â. D. Características da carcaça e da carne de novilhos superjovens da raça Devon terminados em diferentes sistemas de alimentação. Revista Brasileira de Zootecnia, Viçosa, MG, v. 39, n. 3, p. 667-676, 2010.

MONSÓN, F.; SAÑUDO, C.; SIERRA, I. Influence of breed and ageing time on the sensory meat quality and consumer acceptability in intensively reared beef. Meat Science, Oxford, v. 71, n. 3, p. 471-479, 2005.

MORAES, M. A. C. Métodos para avaliação sensorial dos alimentos. Campinas: Editora da UNICAMP, 1993. $93 \mathrm{p}$.

OHLY, J. Prova organoléptica com carnes bubalinas e bovinas de animais criados nas pastagens de várzeas da Amazônia central. Acta Amazonica, Manaus, v. 27, n. 1, p. 33-42, 1997.

OLIVEIRA,A.L. Búfalos: produção, qualidade de carcaça e de carne. Alguns aspectos quantitativos, qualitativos e nutricionais para promoção do melhoramento genéticos. Revista Brasileira de Reprodução Animal, Belo Horizonte, v. 29, n. 2, p. 122-134, 2005.

OLIVER, M. A.; NUTE, G. R.; FONT I FURNOLS, M.; SAN JULIÁN, R.; CAMPO, M. M.; SAÑUDO, C.; CAÑEQUE, V.; GUERRERO, L.; ALVAREZ, I.; DÍAZ, M. T.; BRANSCHEID, W.; WICKE, M.; MONTOSSI, F. Eating quality of beef, from different production systems, assessed by German, Spanish and British consumers. Meat Science, Oxford, v. 74, n. 1, p. 435-442, 2006.

RAES, K.; BALCAEN, A.; DIRINCK, P.; DE WINNE, A.; CLAEYS, E.; DEMEYER, D.; DE SMET, S. Meat quality, fatty acid composition and flavour analysis in Belgian retail beef. Meat Science, Oxford, v. 65, n. 4, p. 1237-1246, 2003. 
RODAS-GONZÁLEZ，A.; HUERTA-LEIDENZ，N.; JEREZ-TIMAURE, N.; MILLER, M. F. Establishing tenderness thresholds of Venezuelan beef steaks using consumer and trained sensory panels. Meat Science, Oxford, v. 83, n. 2, p. 218-223, 2009.

RODRIGUES, V. C.; ANDRADE, I. F. Características físico-químicas da carne de bubalinos e de bovinos castrados e inteiros. Revista Brasileira de Zootecnia, Viçosa, MG, v. 33, n. 6, p. 1839-1849, 2004.

SCHERBECK, J. A.; TATUM, J. D.; FIELD, T. G.; MORGAN, J. B.; SMITH, G. C. Feedlot performance, carcass traits, and palatability traits of Hereford and Hereford x Brahman steers. Journal of Animal Science, Champaign, v. 73, n. 12, p. 3613-3620, 1995.

SCHLINDWEIN, M. M.; KASSOUF, A. L. Análise da influência de alguns fatores socioeconômicos e demográficos no consumo domiciliar de carnes no Brasil. Revista de Economia \& Sociologia Rural (RER), Rio de Janeiro, v. 44, n. 3, p. 549-572, 2006.
SCHNETTLER, B.; SILVA, R.; SEPÚLVEDA, N. Consumo de carne en el sur de Chile y su relación con las características sociodemográficas de los consumidores. Revista Chilena de Nutrición, Santiago, v. 35, p. 262271, 2008. Suplemento 1.

TAMBURO, L. G.; GIL ROIG, J. M. Seguridad alimentaria y comportamiento del consumidor español: el caso de las carnes. Revista Argentina de Economia Agrária, Buenos Aires, v. 6, n. 2, p. 23-41, 2003.

THOMPSON, J. Managing meat tenderness. Meat Science, Oxford, v. 62, n. 3, p. 295-308, 2002.

VILARINHO, R. C.; FISHMANN, M. S.; BERGMANN, G. P.; KINDLEIN, L. Preferência dos consumidores frente a atributos de qualidade de carne bovina comparada a carne bubalina. Revista Higiene Alimentar, São Paulo, v. 25, n. 194-195, p. 1267-1268, 2011.

WARNER, R. D.; GREENWOOD, P. L.; PETHICK, D. W.; FERGUSON, D. M. Genetic and environmental effects on meat quality. Meat Science, Oxford, v. 86, n. 1, p. 171-183, 2010. 
